\title{
Reflections on the biofeedback industry: Its problems and prospects
}

\author{
LEE H. GARLINGTON \\ Newport Beach, California 92663
}

\begin{abstract}
The commercial biofeedback industry is examined and discussed. Suggestions for buying biofeedback instruments are offered.
\end{abstract}

The biofeedback manufacturing industry is just 8 years old and, like any new industry, is experiencing growing pains. An industry that manufactures limited quantities and sells to a limited market frequently begins and develops very much like a human; both are often conceived on the spur of the moment by individuals who are not fully prepared for the consequences. The founders or originators are usually younger than 30 years of age and have usually underestimated the costs and the skills involved. At infancy, growth occurs rapidly and profits are frequently sacrificed for growth. ${ }^{1}$

This paper describes the problems that were faced in developing a new industry and shares with the prospective instrument purchaser the writer's observations on how to select the proper instrument and how to get the best value for his money. Like the adolescent human, one company, Biofeedback Technology, Inc., experienced overconfidence and overspending in order to maintain an image and to increase its market share over its competitors. Violent internal adjustments took place to adjust to new levels of business. Initial manufacturing facilities were small; overhead rose rapidly as secretaries, quality-control engineers, record-keeping clerks, shipping and receiving and other specialty jobs that could no longer be handled by the owner/managers were created. At this stage, competition is usually very intense, with many new companies entering the field headed by equally energetic young entrepreneurs. One rarely sees a large, well-financed company enter the field and begin production, since the volume of business is far too small.

New products are often brought out simply for the sake of having something new to sell. At Biofeedback Technology, the decision to switch emphasis from the then popular EEG to the EMG came in 1973. The decision was based solely on Thomas Budzinsky's work with relaxation and tension headache. There was no field testing of the instruments and very little replication of Budzinsky's work. The company made its decision

Mr. Garlington is the founder and ex-president of Biofeedback Technology, Inc., one of the oldest and largest biofeedback manufacturing companies. The company ceased production in July 1977 . Mr. Garlington, a member of the Biofeedback Society of America since 1970, is currently a consultant in instrumentation and applications. to bring out the first nationally marketed skin temperature trainer after relistening to a tape recording made by Elmer Green of the Meninger Foundation some 6 months after his presentation to the Biofeedback Society of America in 1973 (Green, Sargent, \& Walters, Note 1). Green spoke of training a number of housewives to regulate hand temperatures and of the potential application of the technique to migraine headaches. Within 3 months, Biofeedback Technology manufactured a temperature trainer patterned after the units made in the Topeka area for Green. The instrument was an instant success. In addition, the company created the first digital time-period integrator. Development of this device resulted from a conversation with Joseph Kamiya, who mentioned that this type of instrument was superior to the percent-time indicator, then in wide use, and would make an excellent feedback modality as well. The instrument was introduced in late 1972 but was not an initial success. Today it is considered an essential component of a complete system.

Management at Biofeedback Technology, Inc., underestimated the selling price necessary to cover administrative expenses, especially the cost of advertising and marketing. Losses in operations were made up by personal investments since bank loans and venture capital were almost impossible to obtain. Several of the leading biofeedback companies came dangerously close to going out of business during this period (1974. 1975); there were more than 40 companies in the field at that time. ${ }^{2}$

By mid-adolescence (1976 to the present) casualties began to occur and several companies were out of business. $^{3}$ The industry began to realize its mistakes and raised prices considerably. The price increase, together with a slightly reduced selling cost made possible by a more sophisticated consumer, should have created a reasonable profit margin, but it did not. ${ }^{4}$ Technological advances in electronics and the introduction of computer applications to the field required considerable developmental costs. A higher markup over cost is required on limited production instruments, as the company cannot count on the efficiencies and profits of large production runs to offset a low profit margin. Contrary to what might be believed, the average production run for biofeedback instruments is $25-50$ 
units, with total industry sales at about 6-7 million. ${ }^{5}$

During late adolescence and young adulthood, the human and corporate entity usually explore mergers. In business the first mergers usually occur within existing companies in the field (horizontal merger). Later, when sales are large enough to attract a large multiproduct company, mergers occur with companies totally outside the field (vertical merger). When vertical mergers take place, the field is again under severe stress. The large parent company streamlines production operations and puts considerable funds into research, development, and advertising. Smaller companies are less able to compete and many more go out of business.

Although this generalized scenario sounds rather ominous for the industry, it is not. Those companies with good product loyalty and sound financial management will surely survive in one form or another, and the consumer benefits by enjoying improved products with greater reliability. But there are possible drawbacks: Prices will be higher and the service a little less personal.

\section{PROBLEMS}

I believe that the industry is currently in a late adolescent stage, but the series of horizontal mergers that might be expected may not occur due to the personalities involved. There is no one overriding problem in the industry. There are, however, several nagging pioblems.

\section{Capital}

Money is always a problem in a growth industry. If the industry cannot finance its growth out of profits, it must do so with borrowed or invested money. Borrowed or invested money is very difficult to procure due to the newness of the field and the poor track record of many of the individual companies. Banks look for profits, and profits in this industry are virtually nonexistent.

\section{Price}

The customer may not realize he is getting a good value for his money despite his view that prices are too high. The consumer must understand that the markup over cost must pay for the marketing and service, among many other things, which are considerable compared with more established instruments. Also, time spent by the sales representative at the customer's office should be considered by the customer when evaluating prices. Within the foreseeable future, prices should go up another $10 \%-20 \%$.

\section{Training Programs}

Steps should be taken to increase the usefulness of the instruments and widen their acceptability by providing more information and training. Manuals, video tape, cassette tapes, or slides with emphasis on the operation of the various machines, biofeedback in general, and specific therapeutic techniques should be offered as a package with instrument purchases. A separate company might be formed (jointly owned by two or more companies to reduce the initial costs) to handle training and "software" packaging.

An effort to teach "clinical psychophysiology" in medical schools and psychology departments would be most helpful (see Feuerstein \& Schwartz, 1977).

\section{PERSPECTIVES}

Looking toward the future, I would like to offer some suggestions to industry and the consumer.

\section{Industry}

Mergers should be seriously considered to reduce duplication of products, research, and marketing expenses. The industry should sponsor research on the best types of audio and visual feedback and consider the results in designing new equipment.

\section{Consumer}

Consumers should insist on a full set of schematic circuit diagrams with parts lists. The government and hospitals get them, so should the individual purchaser. Provided with these documents, it is feasible in an emergency to find a biomedical electronic technician to repair your instrument.

Do not be fooled by claims that company " $X$ " is too large to go out of business. The directors of the parent company could dissolve the company by deciding that there is no future in biofeedback or that there is not enough profit in it; the company does not have to go bankrupt.

One does not necessarily have to purchase a complete system from one company. Different companies have different strengths and certain products of one company are superior to others. There is no clearly superior company. Careful shopping can provide a complete system of EEG, EMG, integrator, GSR, and temperature trainer for about $\$ 3,500$. You will also have several salesmen keeping you informed on what is new in the field, advising you of training programs, and introducing you to colleagues using the equipment.

When shopping for instruments, avoid purchasing devices that are priced considerably below the market leaders. In electronics, you generally get what you pay for; a nonfunctioning bargain is not a bargain. Buy only those features you think you will use. The salesmen are all on commission and will suggest and display the top of the line. Ask for a less expensive model. Ask about the features and what good they might do you. From $\$ 495$ to $\$ 2,000$ can be spent for a good EMG, and in most cases the $\$ 495$ device is completely adequate. 
Demand at least a 10-day trial period before any money other than a security deposit changes hands. Use the instrument on yourself extensively. If you don't like it, don't buy it.

Ask the company for references of colleagues using their instruments in your area. Contact them and see if the company honors its warranty and how long it takes for repairs. Find out the features they like and ask why they like them.

After using your choice of instruments for about 6 months, let the president or sales manager know what you like or do not like about it. With such information, companies can change or improve their instruments.

The biofeedback instrumentation market has some well-packaged excellent-quality instruments with functions undreamed of 6 or 7 years ago. In most cases, the customer is getting good value for his money. The road has been a hard one for industry, but the future looks very bright indeed.

\section{REFERENCE NOTE}

1. Green, E., Sargent, W., \& Walters, D. The autoregulation of hand-surface temperature: A pilot project. Paper presented at the annual meeting of the Biofeedback Research Society. 1973.

\section{REFERENCE}

Feuerstein, M., \& Schwartz, G. Training in clinical psychophysiology: Present trends and future goals. American Psychologist, 1977, 32, 560-567.

\section{NOTES}

1. Personal conversations with presidents of biofeedback manufacturing companies and consultations with small business advisors.

2. Personal conversations with presidents of biofeedback manufacturing companies.

3. Alphametrics, Aquarious Electronics, Biodyne, Bioscan, Biofeedback Technology, Inc., Neuronics, and others.

4. Personal observation of income statements of several large biofeedback companies and personal company experience.

5 . Derived through estimates given by three corporate presidents. 